\title{
TOTAL PHENOLIC CONTENT, ANTIOXIDANT CAPACITY AND STARCH HYDROLYTIC ENZYME INHIBITION OF THE EXTRACTS FROM UNPOLISHED COLORED RICES
}

\author{
Le Hoang Dao, Pham Van Hung ${ }^{\bowtie}$ \\ International University, Vietnam National University Ho Chi Minh City \\ ${ }^{\bowtie}$ To whom correspondence should be addressed. E-mail: pvhung@hcmiu.edu.vn
}

Received: 22.3.2017

Accepted: 22.10.2017

\section{SUMMARY}

The different colors of rice are contributed by various phenolic compounds, which have various health benefits. However, phenolic compounds, which are mostly existed in rice bran and easily lost during milling. Therefore, the consumption of unpolished rice is recommended to prevent from many diseases. The objective of this study is to determine total phenolic and flavonoid contents, antioxidant capacity and diabetic enzyme inhibition potential of the extracts of the different unpolished colored rices. Three kinds of unpolished colored rices (unpolished white rice, unpolished red rice and unpolished black rice) grown in Vietnam were used to extract their bioactive compounds by alcoholic solvent extracting method. The results showed that the highest level of total phenolic content (TPC) was found in unpolished red rice (470.96 $\mu \mathrm{g}$ FAE/g db sample), while the lowest was in unpolished white rice (135.84 $\mu \mathrm{g} \mathrm{FAE} / \mathrm{g} \mathrm{db}$ sample). TPC of rice in free form was considerably higher than that in the bound form. Total flavonoid content in free form was also significantly higher than bound form. Total flavonoid content in free form of unpolished black rice (126.75 $\mu \mathrm{g} \mathrm{RE} / \mathrm{g} \mathrm{db}$ sample) was higher than that in the others. In the present study, unpolished red rice extract possessed the best antioxidant activity $(78.79 \%)$ in most cases, and showed the strongest inhibitory potential against alpha-amylase (78.56\%) and amyloglucosidase $(36.13 \%)$ as well. As a result, extracts of unpolished colored rices could act like both antioxidant and enzyme inhibitors and have a potential to be used in prevention of type 2 diabetes.

Keywords: Colored rice, Phenolics, Flavonoids, Antioxidant capacity, Enzyme inhibition

\section{INTRODUCTION}

Phenolic compounds are universally distributed in the plant kingdom as secondary metabolic products. Fruits and vegetables are known as major dietary sources of phenolic compounds, whereas substantial research has demonstrated that cereal consumption is also an excellent way to increase phenolic compound intake. Cereal grains contain free phenolic compounds and a significant amount of insoluble phenolic compounds, most of which are bound to polysaccharides in the cell wall. Both types are important sources of phenolic compounds; however, consumption of these phenolic compounds is currently neglected. The major reason for this is that these compounds are concentrated in the bran layers and are lost with the separation of seed coat during processing. Therefore, most phenolic compounds in rice are also lost with rice bran.

Phenolic compounds having one or more aromatic rings with one or more hydroxyl groups possess high antioxidant and free radical scavenging capabilities. Phenolic compounds in diet may provide health benefits associated with reducing risk of chronic disease such as preventing oxidative damage of lipid and low-density lipoproteins, inhibiting platelet aggregation, and reducing the risk of coronary heart disease and cancer (Liu, 2004; Tian et al., 2004). In rice, Goffman et al., (2004) studied the genotypic and environmental effects on the kernel phenolic content and found that bran color was highly statistically significant for bran phenolic contents. In Vietnam, there are a number of rice varieties with different colors contributed by phenolic compounds and anthocyanin such as black rice, red rice, etc. Therefore, the objective of this 
study was to determine the total phenolic and flavonoid contents and their antioxidant capacities and diabetic enzyme inhibition potential of extracts from unpolished black rice, unpolished red rice and unpolished white rice which can be applied for production of functional food and pharmaceutical medicines.

\section{MATERIALS AND METHODS}

\section{Materials}

Unpolished red rice (Gạo lứt huyết rồng), unpolished white rice (Gạo lứt trắng) and unpolished black rice (Gạo lứt cẩm) used in this study were purchased in local supermarket. Raw materials are ground to flour and storage in room temperature for later use.

Folin-Ciocalteu reagent, 1,1-diphenyl-2-picryl hydrazyl radical (DPPH), ferulic acid, rutin standard, p-nitrophenyl-alpha-D-glucopyranoside and Dinitrosalicylic acid reagent were purchased from Sigma Co. Ltd.

\section{Methods}

Phenolic compounds of rice flours were extracted into free phenolic compounds according to the methods of Adom, Liu (2002). Samples (1g of rice flours) were extracted with $20 \mathrm{ml}$ of $75 \%(\mathrm{v} / \mathrm{v})$ methanol in water or $75 \%(\mathrm{v} / \mathrm{v})$ ethanol in water, separately. The free phenolic compounds were separated by centrifugation and then concentrated by an evaporator to $10 \mathrm{ml}$ in methanol.

Total phenolic content was measured by FolinCiocalteu's method according to Liyana-Pathirana et al., (2006) and expressed as ferulic acid equivalent (FAE). The absorbance of solution was measured at $725 \mathrm{~nm}$ using a spectrophotometer (Genesys 10S UV- Vis, USA). Three replications were prepared to evaluate. The concentration of total phenolic content was calculated by using the standard curves as amount of ferulic acid equivalent.

Total flavonoid content was determined using the colorimetric method described by Chang et al., (2002). The extracts were reacted with aluminum chloride solution and potassium acetate to form a blue color. The absorbance of the solution was measured at $415 \mathrm{~nm}$ using a spectrophotometer (Genesys 10S UV- Vis, USA). The concentration of total phenolic content was calculated by using the standard curves as amount of rutin equivalent.
The antioxidant capacity of the extracts was measured in terms of free radical scavenging ability using the DPPH method according to the method of Bastos et al., (2007).

The $\alpha$-amylase inhibitory activity was determined as described previously (Gao et al., 2008). Alpha-amylase hydrolyzed starch substrate with or without the presence of the extracts. The enzyme reaction was stopped by dinitrosalicylic acid reagent. The absorbance was then measured at 540 $\mathrm{nm}$ using a spectrophotometer (Genesys 10S UVVis, USA).

The amyloglucosidase enzyme inhibition assay was modified according to the method described by Kwon et al., (2008). The p-nitrophenyl- $\alpha$-Dglucopyranoside was used as a substrate and different concentrations of extracts were used as the inhibitors. The results were expressed as \% inhibition of enzyme.

All the tests were done in triplicate and SPSS version 16 software program was used for statistical assessment.

\section{RESULTS AND DISCUSSION}

\section{Total phenolic contents of rice extracts}

As shown in the table 1, the highest level of total phenolic content (TPC) was found in unpolished red rice $(470.96 \mu \mathrm{g}$ FAE/g sample (dry basis, db)), while the lowest was in unpolished white rice $(135.84 \mu \mathrm{g}$ FAE/g sample (db)). TPC of rice in free form was considerably higher than that in the bound form. In the unpolished red rice and unpolished white rice, TPC of free phenolic extracts were 5 times higher than in bound forms, and this number was 3 times in unpolished black rice. The free phenolics increased in order unpolished brown rice $<$ unpolished black rice $<$ unpolished red rice, in which unpolished red rice reached to $392.4 \mu \mathrm{g}$ FAE/g sample (db), nearly 3 times in compared with unpolished white rice of $115.4 \mu \mathrm{g} \mathrm{FAE} / \mathrm{g}$ sample (db). Therefore, the total phenolic content of rice extracts depended mainly on the amount of free form of rice extracts.

Previous study found that unpolished white rice contained large amount of phenolic compounds in compared with white rice (Tian et al., 2004). This could be due to phenolic compounds are mostly located in the bran layer of rice grains. Total phenolic contents of free phenolic extracts of each 
kind of unpolished colored rice were significantly higher than those of the bound phenolic extracts. These results indicate that the phenol compounds in rice existed primarily in free form rather than in bound form and solvent extraction methods were effective methods for phenolic recovery.

Table 1. Total phenolic contents of rice extracts.

\begin{tabular}{|c|c|c|c|}
\hline Rice sample & $\begin{array}{l}\text { Free phenolics } \\
\text { ( } \mu \mathrm{g} \text { FAE/g sample) }\end{array}$ & $\begin{array}{l}\text { Bound phenolics } \\
\text { ( } \mu \mathrm{g} \text { FAE/g sample) }\end{array}$ & $\begin{array}{l}\text { Total phenolics } \\
\text { ( } \mu \mathrm{g} \text { FAE/g sample) }\end{array}$ \\
\hline Unpolished black rice & $223.4 \pm 2.0^{b}$ & $60.6 \pm 1.3^{b}$ & 284.05 \\
\hline Unpolished white rice & $115.4 \pm 4.0^{\mathrm{a}}$ & $20.5 \pm 0.7^{\mathrm{a}}$ & 135.84 \\
\hline Unpolished red rice & $392.4 \pm 2.0^{\mathrm{c}}$ & $78.5 \pm 5.3^{c}$ & 470.96 \\
\hline
\end{tabular}

Note: Data are expressed as mean \pm standard deviation of replicate samples. Mean in each column followed by different letters differ significantly $(p<0.05)$.

\section{Total flavonoid contents of rice extracts}

Total flavonoid content in the free form was also significantly higher than that in the bound form (Table 2 ). In the free form, flavonoid content of unpolished white rice, unpolished red rice and unpolished black rice was 67.10, 83.92 and $126.75 \mu \mathrm{g}$ RE/g sample (db), respectively. Flavonoid contents, in the bound form, ranged 26.8 to $50.29 \mu \mathrm{g} \mathrm{RE} / \mathrm{g}$ sample (db). However, flavonoid content in the free form of unpolished black rice $(126.75 \mu \mathrm{g} R$ R/g sample $(\mathrm{db}))$ were higher than those in the others (unpolished red rice of $83.92 \mu \mathrm{g}$ $\mathrm{RE} / \mathrm{g}$ sample $(\mathrm{db})$ and unpolished white rice of 67.10 $\mu \mathrm{g} R E / g$ sample $(\mathrm{db}))$. A previous study reported that the quantity of flavonoids varied depending on the cultivar and environment effects (Oomah, Mazza, 1996). The deep-colored rice was considered as good source of phenolics, including flavonoids as more healthy to human body, especially in the oriental countries (Qian et al., 2004).

Table 2. Total flavonoid contents of rice extracts.

\begin{tabular}{llll}
\hline Rice sample & $\begin{array}{l}\text { Free phenolics } \\
(\boldsymbol{\mu g ~ R E / g ~ d b ~ s a m p l e ) ~}\end{array}$ & $\begin{array}{l}\text { Bound phenolics } \\
(\boldsymbol{\mu g ~ R E / g ~ d b ~ s a m p l e ) ~}\end{array}$ & $\begin{array}{l}\text { Total phenolics } \\
(\boldsymbol{\mu g} \text { RE/g db sample) }\end{array}$ \\
\hline Black rice & $126.75 \pm 3.14^{\mathrm{c}}$ & $50.29 \pm 2.69^{\mathrm{c}}$ & 177.04 \\
Brown rice & $67.10 \pm 0.45^{\mathrm{a}}$ & $26.80 \pm 0.90^{\mathrm{a}}$ & 93.91 \\
Red rice & $83.92 \pm 0.90^{\mathrm{b}}$ & $37.91 \pm 0.45^{\mathrm{b}}$ & 121.83 \\
\hline
\end{tabular}

Note: Data are expressed as mean \pm standard deviation of replicate samples. Mean in each column followed by different letters differ significantly $(p<0.05)$.

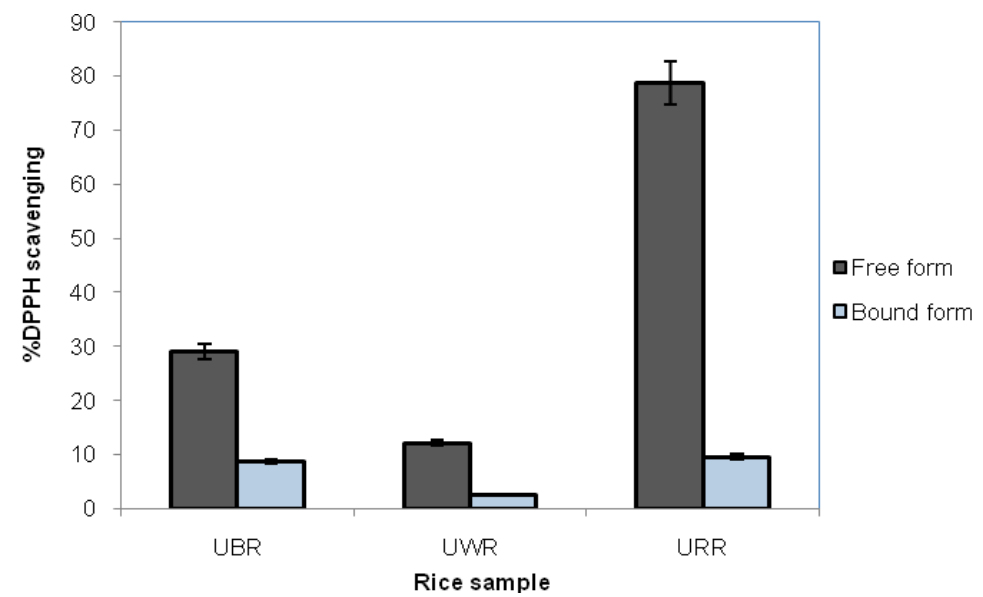

Figure 1. DPPH radical scavenging of free and bound phenolic compounds of rice extracts. UBR, unpolished black rice; UWR, unpolished white rice; URR, unpolished red rice. 


\section{Antioxidant capacity of rice extracts}

Scavenging of stable DPPH radical was widely used to evaluate antioxidant activity of phenolic compounds extracted from cereal, grain, fruits, etc. In this study, the antioxidant activities of the free and bound phenolic extracts of the unpolished colored rices were evaluated using DPPH assay. It based on the measurement of reducing ability of reaction color between DPPH solution and rice extracts. After exactly $30 \mathrm{~min}$, the DPPH of free and bound of phenolic compound was recorded at $515 \mathrm{~nm}$.

Fig. 1 showed the antioxidant capacity of rice extracts. In the free form, DPPH radical scavenging was the highest in unpolished red rice extract $(78.79 \%)$ and the lowest in unpolished white rice extract $(12.15 \%)$. Similarly, in the bound form, the highest level of DPPH radical scavenging was in unpolished red rice extract $(9.53 \%)$, and lowest in unpolished white rice $(2.65 \%)$. Therefore, the unpolished red rice extract have the most antioxidant capacities among three rice extracts. According to Mai et al., (2007) positive relationship among total phenolic contents and radical scavenging activity was found. The results in the present study also suggested that phenolic compounds may play very important role in antioxidant activity.

\section{Alpha-amylase inhibitory capacity of rice extracts}

The alpha-amylase inhibition activities of the rice extracts are shown in fig. 2. As the results, in the free form, the unpolished red rice extract have the highest inhibition activity (78.56\%), whereas the unpolished white rice extract have the lowest inhibition activity $(53.63 \%)$, and the inhibition activity of unpolished black rice extract was $68.16 \%$. Similarly, in the bound form, the inhibition activity was highest in unpolished red rice extract $(48.67 \%)$ and the lowest in unpolished white rice extract $(30.60 \%)$. The phenolic compounds in the free form of the unpolished colored rice in this study always have the higher inhibition activity than those in the bound form.

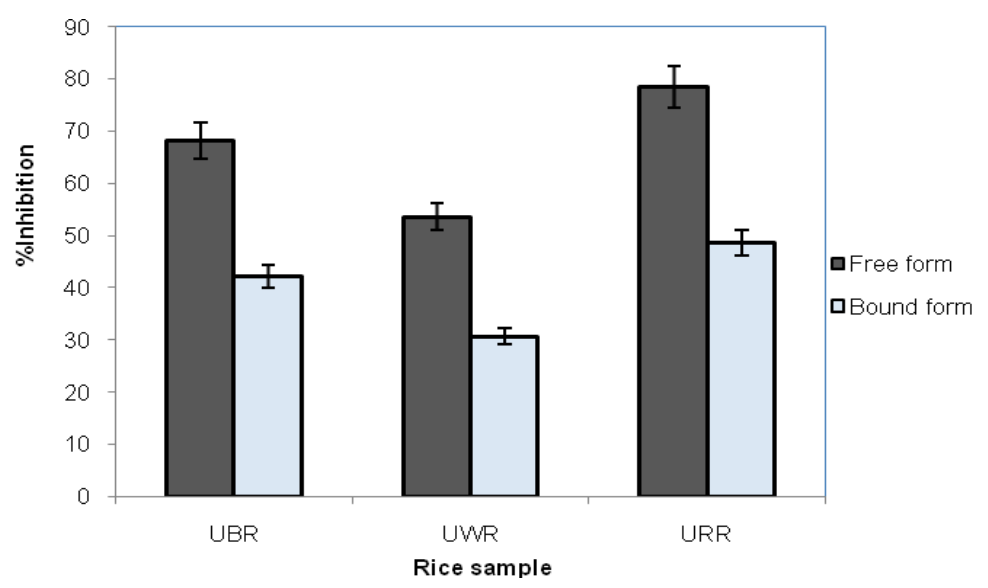

Figure 2. $\alpha$-amylase inhibition activities of free and bound phenolic compounds of rice extracts. UBR, unpolished black rice; UWR, unpolished white rice; URR, unpolished red rice.

\section{Amyloglucosidase inhibitory capacity of rice extracts}

Amyloglucosidase is one of the key enzymes involved in the release of glucose from starch for the intestinal glucose absorption. The inhibition of this enzyme decreases the blood glucose levels and thus it is an important strategy for the management of type 2 diabetes (Plus et al., 1977).

As shown in fig. 3, the amyloglucosidase inhibition activity of free phenolics of rice extracts was significantly higher than that of the bound phenolics. In free phenolics, the inhibition capacity of unpolished red rice extract was highest (36.13\%), nearly 3 times compared with that of the unpolished white rice extract $(11.56 \%)$. In bound phenolics, the inhibition capacity was very low, ranged 1.85 to 7.69 $\%$. As the results, the free form of phenolics always has the higher inhibition activity than the bound form in the extracts of three kinds of unpolished colored rice. These results indicate that the phenolic compounds in rice existed primarily in free form rather than in bound form. 


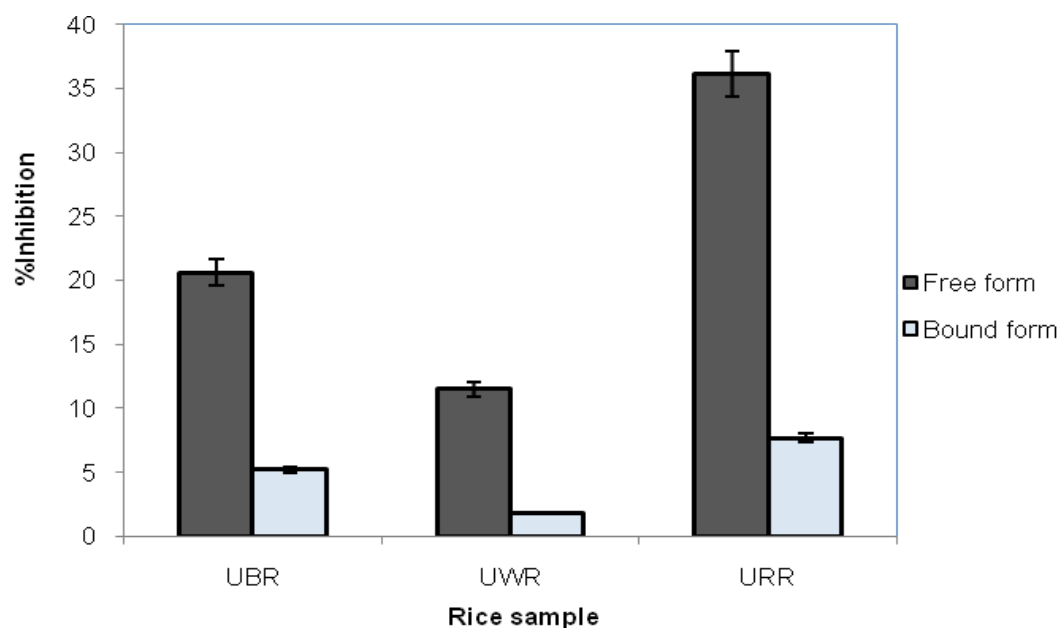

Figure 3. Amyloglucosidase inhibition activities of free and bound phenolic compounds of rice extracts. UBR, unpolished black rice; UWR, unpolished white rice; URR, unpolished red rice.

\section{CONCLUSIONS}

In this study, the unpolished red rice was found to have the highest phenolic content, whereas the unpolished black rice had the highest total flavonoid content. Unpolished red rice and unpolished black rice exhibited high antioxidant capacity and significant alpha-amylase and amyloglucosidase inhibitory potentials. The phenolic content, antioxidant capacity and diabetic enzyme inhibition activity of rice extracts in free form were significantly higher than those in bound form. As a result, the phenolic compound in unpolished colored rice might be used as a functional food to reduce an amount of blood glucose in the diabetic patients.

Acknowledgements: The research is funded by Vietnam National Foundation for Science and Technology Development (NAFOSTED) under grant number 106-NN.99-2015.91.

\section{REFERENCES}

Adom KK, Liu RH (2002) Antioxidant activity of grains. $J$ Agric Food Chem 50: 6182-6187.

Bastos DPH, Saldanha LA, Catharino RR, Sawaya ACHF, Cunha IBS, Carvalho PO, Eberlin MN (2007) Phenolic antioxidants identified by ESI-MS from yerba-maté (Ilex paraguariensis) and green tea (Camelia sinensis) extracts. Molecules 12: 423-432.

Chang C-C, Yang M-H, Wen H-M, Chern J-C (2002)
Estimation of total flavonoid content in propolis by two complementary colorimetric methods. J Food Drug Anal 10: $178-182$.

Gao H, Huang YN, Gao B, Xu PY, Inagaki C, Kawabata J (2008) $\alpha$-Glucosidase inhibitory effect by the flower buds of Tussilago farfara L. Food Chem 106: 1195-1201.

Goffman FD, Bergman CJ (2004) Rice kernel phenolic content and its relationship with antiradical efficiency. $J$ Sci Food Agric 84: 1235-1240.

Kwon YI, Apostolidis E, Shetty K (2008) Inhibition potential of wine and tea against $\alpha$-amylase and $\alpha$ glucosidase for management of hyperglycemia linked to type 2 diabetes. J Food Biochem 32: 15-31.

Liu RH (2004) Potential synergy of phytochemicals in cancer prevention: Mechanism of action. J Nutr 134: 3479-3485.

Liyana-Pathirana CM, Sahidi F (2006) Antioxidant activities of commercial soft and hard winter wheats (Triticum aestivum L.) and their milling fractions. $J$ Sci Food Agric 86: 477-485.

Mai TT, Thu NN, Tien PG, Chuyen NV (2007) Alphaglucosidase inhibitory and antioxidant activities of Vietnamese edible plants and their relationships with polyphenol contents. J Nutr Sci Vitaminol 53(3): 267-276.

Oomah BD, Mazza G (1996) Flavonoids and antioxidant activities in buckwheat. $J$ Agric Food Chem 44: 1746-1750.

Plus W, Keup U, Krause H, Thomos PG, Hoffmeister F (1977) Glucose inhibition: A new approach to the treatment of diabetes, obesity and hyperlipoproteinaemia. Die Naturwissenschaften 64: 536-537. 
Qian J-Y, Liu D, Huang A-G (2004) The efficiency of flavonoids in polar extracts of Lycium chinense Mill fruits as free radical scavenger. Food Chem 87: 283-288.
Tian S, Nakamura K, Kayahara H (2004) Analysis of phenolic compounds in white rice, brown rice, and germinated brown rice, J Agric Food Chem 52: 4808-4813.

\section{HÀM LƯợNG PHENOLIC TỔNG, KHẢ NĂNG KHÁNG OXY HÓA VÀ KHẢ NĂNG Ú̉C CHẾ ENZYME THỦY PHÂN TINH BỘT CỦA DỊCH CHIẾT TƯ CÁC LOẠI GẠO LỨC MANG MÀU}

\section{Lê Hoàng Đạo, Phạm Văn Hùng}

Truờng Đại học Quốc tế, Đại học Quốc Gia Thành phố Hồ Chí Minh

\section{TÓM TẮT}

Màu sắc của các loại gạo là do chúng có chứa các loại chất màu tập trung ở lớp vỏ cám và dễ mất đi trong quá trình xát. Do đó gạo còn chứa lớp vỏ cám (gạo lứt) được khuyến khích sử dụng để phòng chống các bệnh của con người. Nghiên cứu này nhằm xác định hàm lượng phenolic tổng, hàm lượng flavonoid tổng, khả năng kháng oxy hóa và khả năng ức chế các enzyme thủy phân tinh bột của dịch chiết từ các loại gạo lứt có màu khác nhau (gạo lứt cẩm, gạo lứt huyết rồng và gạo lứt trắng). Kết quả cho thấy các chất phenolic trong gạo chủ yếu ở dạng tự do, trong đó gạo lứt huyết rồng có chứa hàm lượng phenolic tổng cao nhất $(470,96 \mu \mathrm{g}$ tương đương ferulic acid $(\mathrm{FAE}) / \mathrm{g}$ gạo), còn gạo lứt trắng có hàm lượng phenolic tổng thấp nhất $(135,84 \mu \mathrm{g} \mathrm{FAE} / \mathrm{g}$ gạo). Hàm lượng flavonoid tổng ở dạng tự do cũng cao hơn so với dạng liên kết. Tuy nhiên, gạo lứt cẩm có chứa hàm lượng flavonoid ở dạng tự do là $126,75 \mu \mathrm{g}$ tương đương rutin/g gạo, cao hơn nhiều so với các loại gạo lứt khác. Trong ba loại gạo, gạo lứt huyết rồng có khả năng kháng oxy hóa cao nhất $(78,79 \%$ hoạt tính kháng gốc tự do DPPH) và khả năng ức chế enzyme amylase và amyloglucosidase cũng cao nhất tương ứng với $78,56 \%$ và $36,13 \%$. Từ kết quả nghiên cứu có thể thấy rằng các loại gạo lứt có màu khác nhau có thể sử dụng như một loại thực phẩm chức năng dùng phòng ngừa bệnh tiểu đường loại 2 .

Tù̀ khóa: Gạo lức, phenolic, flavonoid, chất kháng oxy hóa, chất úc chế enzyme 